\title{
The Effect of Various Hydroxide and Salt Additives on the Reduction of Fluoride Ion Mobility in Industrial Waste
}

\author{
Tadas Dambrauskas ${ }^{1, *(1)}$, Kestutis Baltakys ${ }^{1}$, Agne Grineviciene ${ }^{1}$ and Valdas Rudelis ${ }^{2}$ \\ 1 Department of Silicate Technology, Kaunas University of Technology, LT-50270 Kaunas, Lithuania; \\ kestutis.baltakys@ktu.lt (K.B.); agne.grineviciene@ktu.lt (A.G.) \\ 2 JSC “Lifosa”, LT-57502 Kedainiai, Lithuania; v.rudelis@lifosa.com \\ * Correspondence: tadas.dambrauskas@ktu.lt
}

Citation: Dambrauskas, T.; Baltakys, K.; Grineviciene, A.; Rudelis, V. The Effect of Various Hydroxide and Salt Additives on the Reduction of Fluoride Ion Mobility in Industrial Waste. Sustainability 2021, 13, 1554. https://doi.org/10.3390/su13031554

Academic Editor: Dimitrios Komilis Received: 15 January 2021

Accepted: 29 January 2021

Published: 2 February 2021

Publisher's Note: MDPI stays neutral with regard to jurisdictional claims in published maps and institutional affiliations.

Copyright: (c) 2021 by the authors. Licensee MDPI, Basel, Switzerland. This article is an open access article distributed under the terms and conditions of the Creative Commons Attribution (CC BY) license (https:// creativecommons.org/licenses/by/ $4.0 /)$.

\begin{abstract}
In this work, the influence of various hydroxide and salt additives on the removal of $\mathrm{F}^{-}$ ions from silica gel waste, which is obtained during the production of $\mathrm{AlF}_{3}$, was examined. The leaching of the mentioned ions from silica gel waste to the liquid medium was achieved by the application of different techniques: (1) leaching under static conditions; (2) leaching under dynamic conditions by the use of continuous liquid medium flow; and (3) leaching in cycles under dynamic conditions. It was determined that the efficiency of the fluoride removal from this waste depends on the $\mathrm{w} / \mathrm{s}$ ratio, the leaching conditions, and the additives used. It was proven that it is possible to reduce the concentration of fluorine ions from $10 \%$ to $<5 \%$ by changing the treatment conditions and by adding alkaline compounds. The silica gel obtained after the leaching is a promising silicon dioxide source.
\end{abstract}

Keywords: fluorine ions; silica gel waste; leaching; hydroxide additives

\section{Introduction}

Waste management and the reduction of pollution are the priority areas of environmental protection in the World [1-4]. According to the data of Eurostat [5], the European Union generates approximately 180 million tons of manufacturing waste every year. From an economic point of view, it is preferable to store waste in landfill sites, but they occupy large areas, and are concentrated sources of air, groundwater and soil pollution [6-10]. Therefore, the search for attractive industrial waste recycling treatments, which will allow us to develop products of high value, has become very important.

The global production of aluminum fluoride $\left(\mathrm{AlF}_{3}\right)$ reaches 1 million tons per year, while the amount of generated waste is more than 3 million tons [11-14]. It is worth noting that more than $60 \%$ of this waste is contaminated with fluorine ions, the concentrations of which can reach up to $10 \%$. According to the literature, more than $20 \%$ of the aluminum fluoride in the world is produced by neutralizing hexafluorosilicic acid with aluminum hydroxide $[11,13,15]$ :

$$
\mathrm{H}_{2} \mathrm{SiF}_{6}+2 \mathrm{Al}(\mathrm{OH})_{3} \rightarrow 2 \mathrm{AlF}_{3}+\mathrm{SiO}_{2} \cdot \mathrm{nH}_{2} \mathrm{O}+\mathrm{H}_{2} \mathrm{O}+\mathrm{Q}
$$

However, during the acid neutralization, about 0.67 tons of silica gel contaminated with fluoride ions are generated and stored in the landfill sites [11,13,15-17]. Furthermore, many manufacturers use an amount of hexafluorosilicic acid $\left(\mathrm{H}_{2} \mathrm{SiF}_{6}\right)$ in excess of the amount that the added aluminum hydroxide would fully react, and the yield of aluminum fluoride would increase [11-18]. However, very low $\mathrm{pH}$ values of the obtained system are produced, leading to the strong chemisorption properties of silica gel for fluoride ions [17,19-21]. For this reason, the purification of this material has become a great challenge [19]. Few attempts have been made to reduce the amount of fluoride ions in silica gel waste by leaching [22,23]. None of the experiments were successful enough. 
For this reason, the scientific literature is mostly focused on the search for alternative routes, using silica gel waste as a raw material for the synthesis of commercial value products, or as an additive in binding materials [17,20-22,24,25]. Vaiciukyniene et al. [17,26] investigated the possibility of the utilization of silica gel waste in cement stone. The authors found that the compressive strength of the standard concrete samples decreased by increasing the amount of silica gel waste (up to 15\%). Furthermore, these authors determined that the addition of $10 \%$ silica gel waste calcined at $800{ }^{\circ} \mathrm{C}(1 \mathrm{~h})$ had a positive effect on the compressive strength values of the samples, which increased by $\sim 5-7 \mathrm{MPa}$. However, these studies did not provide any data on the stability of the fluoride ions in cement stone or during calcination.

In other research, silica gel waste was used for the production of alkali-activated blends [27]. It was found that the compressive strength values of hardened samples of silica gel and clay, which were additionally treated with sodium hydroxide and calcined at $600{ }^{\circ} \mathrm{C}(3 \mathrm{~h})$, were equal to 6-17.50 MPa. Krivenko et al. [28] investigated the influence of sodium silicate $\left(\mathrm{Na}_{2} \mathrm{SiO}_{4}\right)$ activated silica gel waste on the hydration characteristics of cement samples. It was found that the additive changes the mechanism of early hydration: (1) increase the amount of heat released during the main hydration reaction; (2) prolong the duration of the induction period; and (3) promote the crystallization of both crystalline and amorphous calcium silicates hydrates and calcium aluminate hydrates. The discussed studies [17,26-28] did not determine the durability of the samples or the stability of the fluorine ions.

R. Kaminskas et al. $[21,25,29,30]$ found that, after the calcination of a mixture containing $20 \%$ clay and $80 \%$ silica gel waste at $600{ }^{\circ} \mathrm{C}$, its pozzolanic activity increased two times, equal to 230-260 mg CaO/g. Further studies have shown that, in order to bind fluorine ions to the stable compounds, 10-20\% limestone must be used in the production of the pozzolanic additive. It was also found that by replacing a part of the cement with a synthetic additive (5-15 wt\%) in the concrete products, the compressive strength values of the samples increased to $5 \%$.

Another potential application of silica gel waste is the synthesis of calcium silicates hydrates [21,31]. However, the obtained products contain fluoride ions which limit their application. Furthermore, silica gel waste can be used for the synthesis of NaA zeolite [20]. The authors found that this zeolite can be synthesized by the sonication of suspensions of silica gel, aluminum hydroxide, sodium hydroxide, and water. Finally, Sarkar et al. [32] found that the use of silica gel with impurities in the production of white porcelain can reduce the burning temperature of products without compromising their performance.

However, the applicability of the mentioned products is limited due to the presence of fluorine ions in the structure of the final product. Therefore, another method could be to leach it from silica gel waste, which later on could be used as an adsorbent or silica source. In the previous work [19], it was determined that it is possible to reduce the quantity of $\mathrm{F}^{-}$ions by more than two times by applying different leaching techniques. However, due to the strong adsorption properties of silica gel waste, the amount of water required for the leaching process is very high $(\mathrm{w} / \mathrm{s}=100)$. It is known that, by increasing the $\mathrm{pH}$ values of system up to $>4$, the framework of silica gel is destroyed and it loses its adsorption properties. In order to increase the mentioned value, silica gel waste should be treated using alkaline (various synthetic or natural) additives, which could improve the physicochemical properties of amorphous silicon dioxide $\left(\mathrm{SiO}_{2} \cdot \mathrm{nH}_{2} \mathrm{O}\right)$. On the other hand, by using additives at the same time, the formation of other by-products could be avoided.

For this reason, the aim of this work is to determine the influence of various hydroxide and salt additives on the removal of $\mathrm{F}^{-}$ions from the silica gel waste obtained from the production of $\mathrm{AlF}_{3}$. 


\section{Materials and Methods}

\subsection{Materials}

Silica gel waste (SGW)-i.e., a waste product of the production of $\mathrm{AlF}_{3}$ in the chemical plant of JSC 'Lifosa' (Kèdainiai, Lithuania)—was dried for $48 \mathrm{~h}$ at $50{ }^{\circ} \mathrm{C}$. The XRF analysis data showed that SGW consists of $36.2 \%$ silica (which is equivalent to $78.9 \% \mathrm{SiO}_{2}$ ), $2.5 \%$ $\mathrm{Al}^{3+}$ ions, and traces of other elements. Meanwhile, the chemical analysis data showed that SGW contains $10.0 \% \mathrm{~F}^{-}$ions. These results were in good agreement with the data of the XRD analysis: aluminum fluoride trihydrate $\left(\mathrm{AlF}_{3} \cdot 3 \mathrm{H}_{2} \mathrm{O}\right)$ and amorphous silicon dioxide, which corresponds to a broad basal reflection in the $18-37^{\circ}$ diffraction angle range, were observed in the XRD pattern of SGW (Figure 1). The results of the particle size distribution analysis showed that the diameter of the SGW particles varied within the $0.03-170 \mu \mathrm{m}$ range, while particles with a size of $34-72 \mu \mathrm{m}$ were dominant. It was also determined that the surface area and the density of the silica gel waste were equal to $281.01 \mathrm{~m}^{2} / \mathrm{kg}$ and $2141 \mathrm{~kg} / \mathrm{m}^{3}$, respectively. The detailed description of the SGW's chemical and physical properties are available in reference [19].

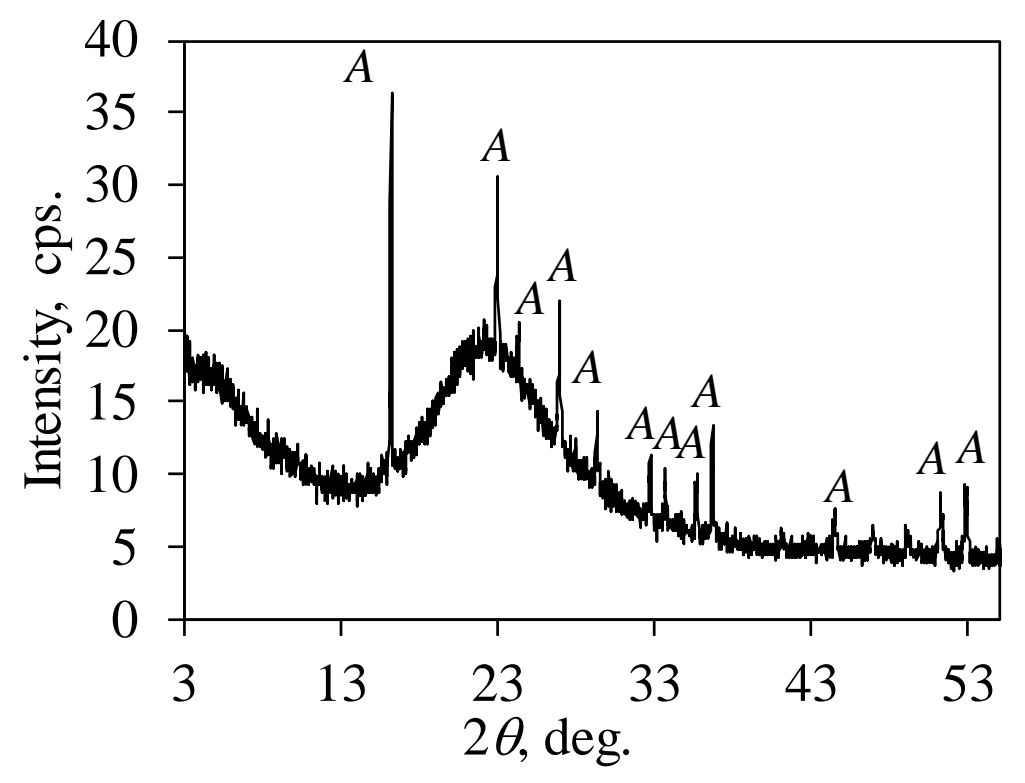

Figure 1. XRD patterns of the SGW. Indexes: $A-\mathrm{AlF}_{3} \cdot 3 \mathrm{H}_{2} \mathrm{O}$.

Chemicals of the following characteristics were used: aluminum hydroxide $\left(\mathrm{Al}(\mathrm{OH})_{3}\right.$, 'Honeywell', Düsseldorf, Germany) purity > 99\%; calcium hydroxide $\left(\mathrm{Ca}(\mathrm{OH})_{2}\right.$, 'Stanchem Sp. J.', Niemce, Poland), purity > 97\%; potassium hydroxide (KOH, 'Reachem', Petrzalka, Slovakia), purity > 99\%; sodium hydroxide ( $\mathrm{NaOH}$, 'Reachem', Petrzalka, Slovakia), purity > 99\%; potassium chloride ( $\mathrm{KCl}$, 'Honeywell', Düsseldorf, Germany), purity > 99\%; ammonium hydroxide ( $\mathrm{NH}_{4} \mathrm{OH}$, 'Lachema', Reckovice, Czech Republic, and JSC 'Lifosa').

\subsection{Methodology}

In this work, the following leaching experiments were performed:

(1) The leaching of $\mathrm{F}^{-}$ions under static conditions: silica gel waste was mixed with the required amount of additive and liquid medium, and kept for $24 \mathrm{~h}$ at $25^{\circ} \mathrm{C}$. After the leaching, the suspensions were filtered off, and the products were dried at $50 \pm 5{ }^{\circ} \mathrm{C}$ for $24 \mathrm{~h}$.

(2) The leaching of $\mathrm{F}^{-}$ions by the use of continuous liquid medium (by applying vacuum $0.6-0.7$ bar) flow, which was applied to silica gel waste. After the process, the products were dried at $50 \pm 5{ }^{\circ} \mathrm{C}$ for $24 \mathrm{~h}$.

(3) The leaching of $\mathrm{F}^{-}$ions in cycles by the use of continuous liquid medium flow. In total, $10 \mathrm{~g} \mathrm{SGW}$ was treated with $50 \mathrm{~mL}$ liquid medium in each step until the w/s 
ratio reached 10-100. After each cycle, the obtained products were filtered off and dried $\left(50 \pm 5{ }^{\circ} \mathrm{C} ; 24 \mathrm{~h}\right)$ at the end of the process.

The X-ray diffraction analysis (XRD) was performed on a D8 Advance diffractometer (Bruker AXS, Karlsruhe, Germany) operating at $\mathrm{U}=40 \mathrm{kV}$ and $\mathrm{I}=40 \mathrm{~mA}$. The X-ray beam was filtered with $\mathrm{Ni} 0.02 \mathrm{~mm}$ filter in order to select the $\mathrm{CuK} \alpha$ wavelength. The diffraction patterns were recorded in a Bragg-Brentano geometry by the use of a fast counting detector Bruker LynxEye. The samples were scanned over the range $2 \theta=3-70^{\circ}$ at a scanning speed of $6^{\circ} \mathrm{min}^{-1}$.

The quantitative chemical composition analysis of the samples was performed using an X-ray fluorescence spectroscopy (XRF) on a Bruker X-ray S8 Tiger WD spectrometer equipped with an Rh tube with an energy of up to $60 \mathrm{keV}$. The powder samples were measured in the Helium atmosphere, and the data were analyzed with SPECTRAPlus QUANT EXPRESS standardless software.

For the determination of the fluoride in the solid, a $1 \mathrm{~g}$ sample was placed on a platinum plate and mixed with $10 \mathrm{~g} \mathrm{NaOH}$ and $\mathrm{KOH}$ mixture (5:7). After that, the platinum plate was placed on the sand bath and heated until the mixture was melted. During the heating, the mixture was vigorously stirred with a platinum spatula before being left to cool down. Afterward, $150 \mathrm{~cm}^{3}$ distilled water was poured into the platinum plate and heated on the sand bath until the formed salts were melted. Then, in order to bind the fluoride ions, $15 \mathrm{~g}$ chemically pure $\left(\mathrm{NH}_{4}\right)_{2} \mathrm{CO}_{3}$ powder was added into the solution and evaporated until a dry salt was formed. After that, the residue was mixed with $150 \mathrm{~cm}^{3}$ distilled water and heated. A hot solution with precipitates was poured into a $250 \mathrm{~cm}^{3}$ flask and cooled down. Then, it was diluted with water to the indicated level and filtered off. Before the measurements were taken, TISAB II was added to each sample (volume ratio 1:1).

The concentrations of the fluoride ions in the solution were measured by the use of a Metler Toledo T70 potentiometer. The error of the selective electrode for $\mathrm{F}^{-}$ions is $<1 \mathrm{ppm}$ $(0.0001 \%)$. The concentration of the $\mathrm{F}^{-}$ions was calculated as the arithmetic mean of the 3 individual results. The measurements' deviations were below $3 \%$.

\section{Results and Discussion}

\subsection{The Effect of Aluminium Hydroxide on the Mobility of $F^{-}$Ions in the Silica Gel Waste Samples}

It is known that aluminum hydroxide has amphoteric properties, i.e., it is able to donate or accept protons and react with both acids and bases. Furthermore, $\mathrm{Al}(\mathrm{OH})_{3}$ dissolves in water, and-under certain conditions-produces $\mathrm{H}^{+}$or $\mathrm{OH}^{-}$ions:

$$
3 \mathrm{H}^{+}+\mathrm{AlO}_{3}^{3-} \leftrightarrow \mathrm{Al}^{3+}+3 \mathrm{OH}^{-}
$$

As the $\mathrm{pH}$ of the silica gel waste is strongly acidic, different amounts of aluminum hydroxide, which were equivalent to $2.5,5,7.5$ and $10 \% \mathrm{Al}^{3+}$ ions from the mass of the dry materials, were added to the SGW samples and mixed in a homogenizer (Turbula type T2F) for $1 \mathrm{~h}$ at $30 \mathrm{rpm}$. Later, the samples were treated with water under static and dynamic conditions.

It was determined that, after $24 \mathrm{~h}$ of the treatment of the SGW with $\mathrm{Al}(\mathrm{OH})_{3}$ additive $(2.5-10 \%)$ under static conditions, the intensity of the diffraction peaks characteristic to $\mathrm{AlF}_{3} \cdot 3 \mathrm{H}_{2} \mathrm{O}$ only slightly decreased, when the water-to-solid ratio was equal to 6 (Figure 2). Meanwhile, the intensity of the main diffraction maximum of $\mathrm{Al}(\mathrm{OH})_{3}$ (d-spacing: $0.547 \mathrm{~nm}$ ) increased from 0 (without additive) to $185 \mathrm{cps}$ (when $10 \%$ additive was used). Meanwhile, the increment of the water-to-solid ratio to $100 \mathrm{had}$ a positive effect on the decomposition of the $\mathrm{AlF}_{3} \cdot 3 \mathrm{H}_{2} \mathrm{O}$ in the mixtures with $2.5 \% \mathrm{Al}^{3+}$ ions, because the intensities of the diffraction maximums typical to the latter compound decreased more than five times (Figure 2). It should be noted that, when the $\mathrm{Al}(\mathrm{OH})_{3}$ additive is not used and the SGW is treated with water $(\mathrm{w} / \mathrm{s}=100,24 \mathrm{~h})$, the intensity of the diffraction peaks characteristic of $\mathrm{AlF}_{3} \cdot 3 \mathrm{H}_{2} \mathrm{O}$ decreased only three times [19]. 


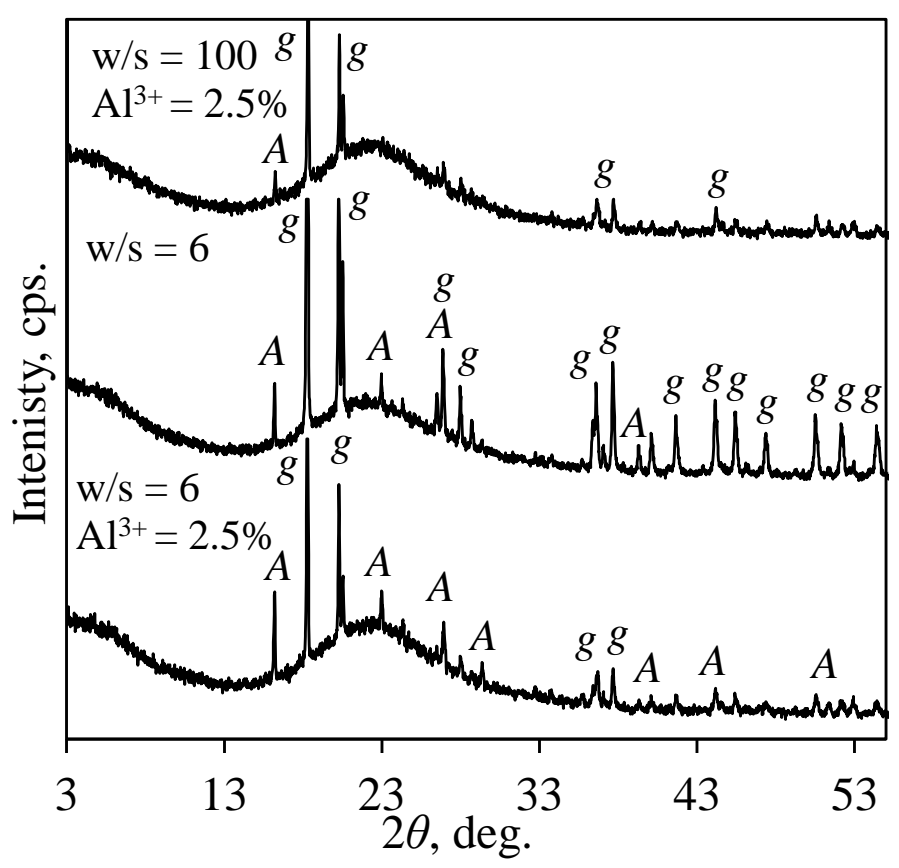

Figure 2. XRD patterns of the products obtained after the treatment of $\mathrm{SGW}$ with $\mathrm{Al}^{3+}$ ions under static conditions. Indexes: $A-\mathrm{AlF}_{3} \cdot 3 \mathrm{H}_{2} \mathrm{O} ; g-\mathrm{Al}(\mathrm{OH})_{3}$.

Moreover, it was found that the $\mathrm{pH}$ values of the liquid medium separated from the SGW samples after the treatment with water $(\mathrm{w} / \mathrm{s}=6)$ depended on the amount of $\mathrm{Al}^{3+}$ ions used (Table 1 ). When $2.5 \%$ of the mentioned ions were added to the system, the $\mathrm{pH}$ of the liquid medium reached 2.54; meanwhile, at higher concentrations of $\mathrm{Al}^{3+}$ ions $(\geq 5 \%)$, this parameter was increased to $4.41-4.73$ (Table 1$)$. It should be noted that, in the same treatment conditions, the $\mathrm{pH}$ value of the liquid medium was $\sim 2.4$ times higher in comparison with the samples without aluminum ions [19]. However, the amount of $\mathrm{F}^{-}$ ions released to the liquid medium was insignificant (Table 1).

Table 1. The amount of $\mathrm{F}^{-}$ions and the $\mathrm{pH}$ values of the liquid medium after the treatment of the $\mathrm{SGW}$ with $\mathrm{Al}^{3+}$ ions under static conditions.

\begin{tabular}{ccccc}
\hline $\begin{array}{c}\text { The Amount of } \mathbf{A l}^{3+} \\
\text { Additive, } \%\end{array}$ & w/s Ratio & $\begin{array}{c}\text { The Concentration of } \mathbf{F}^{-} \\
\text {Ions in the Sample, } \%\end{array}$ & $\begin{array}{c}\text { The Amount of } \\
\text { Released } \mathbf{F}^{-} \text {Ions, \% }\end{array}$ & $\begin{array}{c}\text { The pH Value of the } \\
\text { Liquid Medium }\end{array}$ \\
\hline 2.5 & 6 & - & - & 2.54 \\
5 & 6 & - & - & 4.41 \\
7.5 & 6 & - & 5.18 & 4.60 \\
10 & 6 & 9.51 & 55.43 & 4.73 \\
2.5 & 100 & 4.47 & 3.06 \\
\hline
\end{tabular}

Furthermore, when the w/s ratio was increased to 100 and $2.5 \% \mathrm{Al}^{3+}$ ions were used, the $\mathrm{pH}$ value of the liquid medium reached 3.06 (Table 1 ). In this case, more than $55 \%$ of the initial amount of $\mathrm{F}^{-}$ions were released from the structure of the sample into the liquid medium (Table 1). It should be noted that this is $\sim 6 \%$ more than in the samples without an additive [19].

Since the amount of $\mathrm{Al}(\mathrm{OH})_{3}$ additive does not affect the stability of $\mathrm{AlF}_{3} \cdot 3 \mathrm{H}_{2} \mathrm{O}$, the leaching in cycles under dynamic conditions (10 g SGW was treated with $50 \mathrm{~mL}$ liquid medium) was achieved by the use of $\mathrm{Al}(\mathrm{OH})_{3}$, the quantity of which corresponded to $2.5 \% \mathrm{Al}^{3+}$ ions. It was determined that the intensities of the diffraction peaks characteristic to $\mathrm{AlF}_{3} \cdot 3 \mathrm{H}_{2} \mathrm{O}$ only slightly decreased, and the concentration of $\mathrm{F}^{-}$ions decreased only to $\sim 9 \%$ when the $\mathrm{w} / \mathrm{s}$ ratio was equal to 20 (Figure 3, Table 2). By increasing the w/s ratio to 100 , it was observed that a small amount of $\mathrm{AlF}_{3} \cdot 3 \mathrm{H}_{2} \mathrm{O}$ was still present in the sample, 
because only low intensity diffraction peaks were identified in the XRD patterns (Figure 3). Moreover, the quantity of the fluorine ions released into the liquid medium was estimated to be $\sim 2.5 \%$ higher (Table 2) than in the samples treated under static conditions (Table 1).

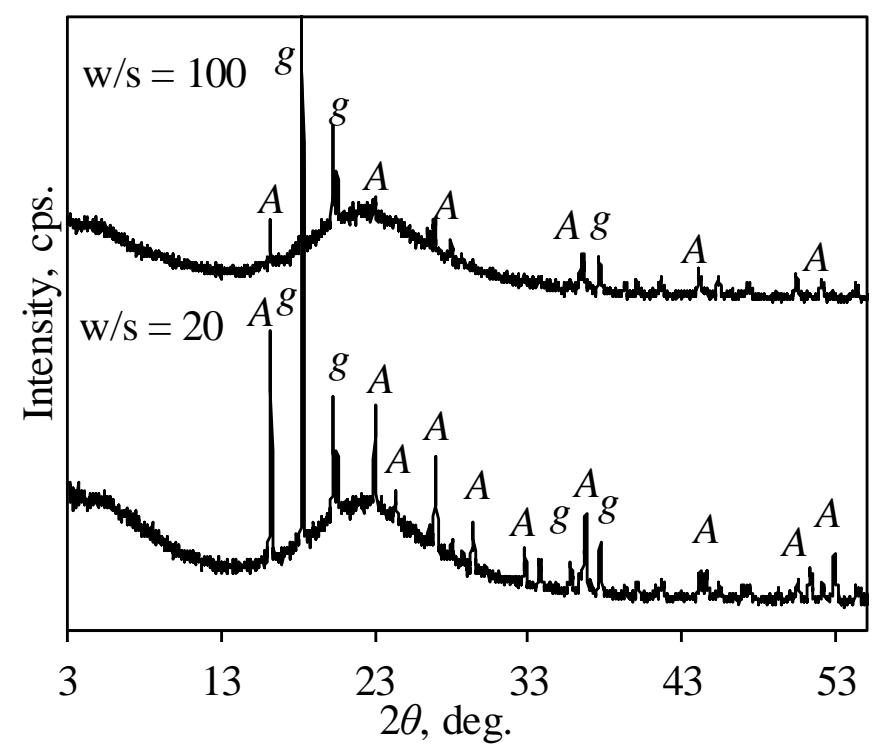

Figure 3. XRD patterns of the products obtained after the treatment of SGW with $\mathrm{Al}^{3+}$ ions in cycles under dynamic conditions. Indexes: $A-\mathrm{AlF}_{3} \cdot 3 \mathrm{H}_{2} \mathrm{O} ; g-\mathrm{Al}(\mathrm{OH})_{3}$.

Table 2. The concentration of $\mathrm{F}^{-}$ions in the SGW with $2.5 \% \mathrm{Al}^{3+}$ ions after treatment in cycles under dynamic conditions.

\begin{tabular}{cccc}
\hline Number of Cycles & w/s Ratio & The Concentration of $\mathbf{F}^{-}$Ions in the Sample, $\%$ & The Amount of Released $\mathrm{F}^{-}$Ions, $\%^{\text {\% }}$ \\
\hline 4 & 20 & 9.06 & 9.67 \\
20 & 100 & 4.22 & 57.93 \\
\hline
\end{tabular}

The results of the liquid medium analysis showed that the duration of one cycle (filtration/interaction) was equal to $\sim 40 \mathrm{~s}$; thus, the total interaction time was $13 \mathrm{~min}$, which is significantly shorter in comparison to the static conditions $(24 \mathrm{~h})$. Moreover, the $\mathrm{pH}$ value of the liquid medium reached $\sim 3$ when the $\mathrm{w} / \mathrm{s}$ ratio was equal to 10 (Figure 4). The further increment in the $\mathrm{w} / \mathrm{s}$ ratio (30-100) resulted in a $\mathrm{pH}$ value of 4.2.

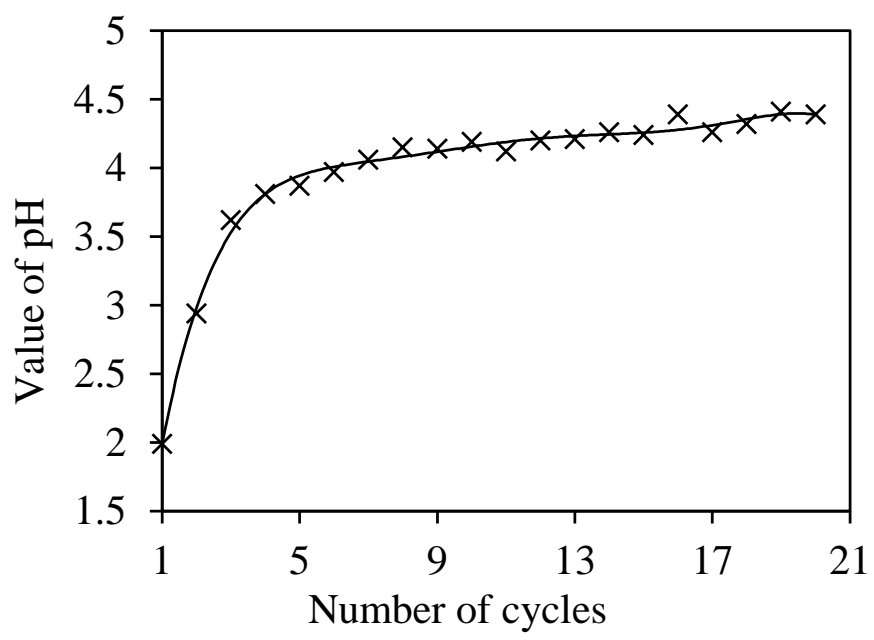

Figure 4. The change in the $\mathrm{pH}$ values of the liquid medium during the treatment in cycles. 
In a previous work, it was determined that, by the use of treatment with water at $25{ }^{\circ} \mathrm{C}$, the $\mathrm{F}^{-}$ion concentration in silica gel waste can be reduced by up to $49 \%$ [19]. Meanwhile, by adding $2.5 \% \mathrm{Al}^{3+}$ ions to $\mathrm{SGW}$, the $\mathrm{F}^{-}$ion concentration can be reduced by up to $58 \%$ (Tables 1 and 2). Thus, it can be stated that the $\mathrm{Al}(\mathrm{OH})_{3}$ additive positively affected the removal of $\mathrm{F}^{-}$ions from the structure of the silica gel in the liquid medium.

In the next part of this work, it was decided to investigate the influence of another hydroxide (calcium hydroxide) on the mentioned process.

\subsection{The Effect of Calcium Hydroxide on the Mobility of $F^{-}$Ions in Silica Gel Waste Samples}

According to the literature $[33,34]$, the application of $\mathrm{Ca}(\mathrm{OH})_{2}$ can not only induce the release of $\mathrm{F}^{-}$ions, but can also bind these ions into a stable calcium fluoride compound $\left(\mathrm{CaF}_{2}\right)$.

The treatment of contaminated silica gel with a $\mathrm{Ca}(\mathrm{OH})_{2}$ additive was first performed under static conditions. In order to decrease the amount of $\mathrm{F}^{-}$ions, 6.5 and $20 \% \mathrm{Ca}(\mathrm{OH})_{2}$ were added to the SGW sample, along with a w/s ratio equal to 10 and a treatment temperature of $25{ }^{\circ} \mathrm{C}$. It is worth noting that the maximum amount of the additive (20\%) was sufficient enough to combine all of the fluorine ions into $\mathrm{CaF}_{2}$. It was determined that, after the treatment of the SGW samples with $6.5 \% \mathrm{Ca}(\mathrm{OH})_{2}$, the $\mathrm{AlF}_{3} \cdot 3 \mathrm{H}_{2} \mathrm{O}$ was fully decomposed, and the $\mathrm{F}^{-}$ions were bound into $\mathrm{CaF}_{2}$ (Figure 5). Furthermore, aluminum fluoride hydroxide hydrate $\left(\mathrm{AlF}_{1.5}(\mathrm{OH})_{1.5} \cdot 0.375 \mathrm{H}_{2} \mathrm{O} ; d\right.$-spacing: 0.568, 0.296, $\left.0.284 \mathrm{~nm}\right)$, a product of $\mathrm{AlF}_{3} \cdot 3 \mathrm{H}_{2} \mathrm{O}$ decomposition, was identified in the XRD patterns. Moreover, the increment in the quantity of the additive to $20 \%$ did not affect the mineral composition of the formed compounds (Figure 5). The results of chemical analysis showed that, in both cases, $\mathrm{F}^{-}$ions were not released into the liquid medium. Furthermore, it was found that the amount of the additive determined the $\mathrm{pH}$ of the liquid medium, the values of which were equal to 7.1 (by the use of $6.5 \% \mathrm{Ca}(\mathrm{OH})_{2}$ ) and 11.7 (by the use of $\left.20 \% \mathrm{Ca}(\mathrm{OH})_{2}\right)$.

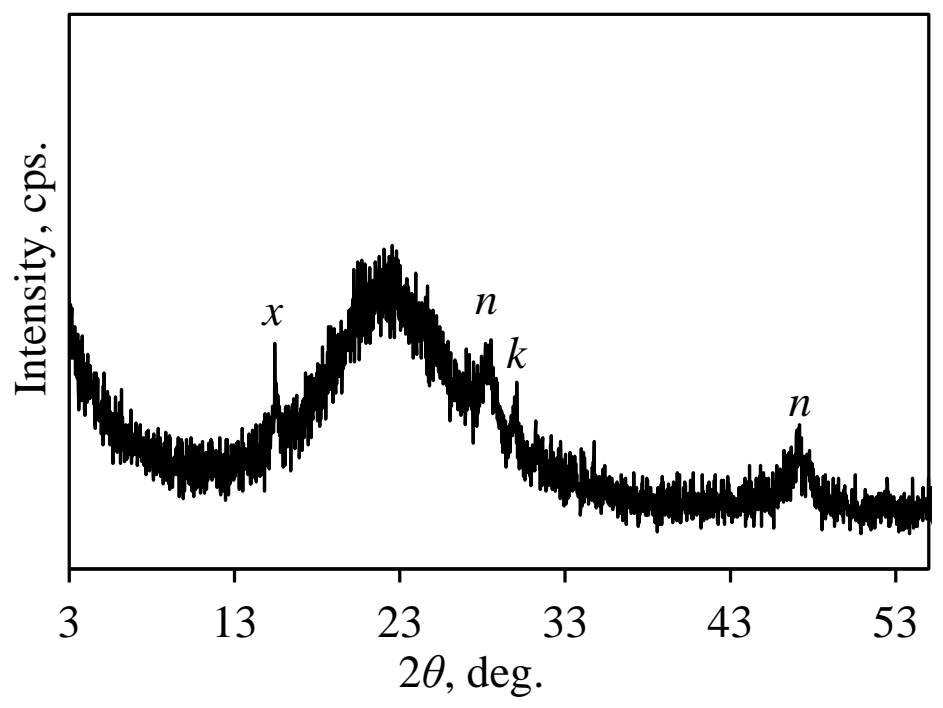

Figure 5. XRD patterns of the products obtained after the treatment of SGW with $6.5 \% \mathrm{Ca}(\mathrm{OH})_{2}$ under static conditions $(24 \mathrm{~h}, \mathrm{w} / \mathrm{s}=10)$. Indexes: $n-\mathrm{CaF}_{2} ; x-\mathrm{AlF}_{1.5}(\mathrm{OH})_{1.5} \cdot 0.375 \mathrm{H}_{2} \mathrm{O} ; k-\mathrm{CaCO}_{3}$.

It can be stated that the $\mathrm{Ca}(\mathrm{OH})_{2}$ additive has a positive effect on $\mathrm{AlF}_{3} \cdot 3 \mathrm{H}_{2} \mathrm{O}$ decomposition; however, the $\mathrm{F}^{-}$ions were bound into $\mathrm{CaF}_{2}$, or were absorbed into the silica gel sample and remained in the solid material. Similar results were obtained by Iljina et al. [22]. These authors showed that, by treating SGW under static conditions at different temperatures and $\mathrm{w} / \mathrm{s}$ ratios, the $\mathrm{F}^{-}$ion concentration can be reduced to only $6-7 \mathrm{wt} \%$. For this reason, in the next stage of this work, the silica gel samples were treated with a saturated $\mathrm{Ca}(\mathrm{OH})_{2}$ solution under dynamic conditions. 
It was determined that the treatment conditions affect the stability of $\mathrm{AlF}_{3} \cdot 3 \mathrm{H}_{2} \mathrm{O}$ and the removal of $\mathrm{F}^{-}$ions. After the leaching of the $\mathrm{F}^{-}$ions by the use of continuous liquid medium flow ( $\mathrm{w} / \mathrm{s}=25,50,100$ ), low diffraction peaks characteristic of $\mathrm{AlF}_{3} \cdot 3 \mathrm{H}_{2} \mathrm{O}$ and its decomposition product, $\mathrm{AlF}_{1.5}(\mathrm{OH})_{1.5} \cdot 0.375 \mathrm{H}_{2} \mathrm{O}$, were still observed in the XRD patterns (Figure 6, curves 1-4). As expected, together with the mentioned compounds, $\mathrm{CaF}_{2}$ and $\mathrm{CaCO}_{3}$ (formed due to the interaction between $\mathrm{Ca}(\mathrm{OH})_{2}$ and atmospheric $\mathrm{CO}_{2}$ ) were detected. Meanwhile, when the silica gel waste was treated in cycles $(\mathrm{w} / \mathrm{s}=100)$, $\mathrm{AlF}_{3} \cdot 3 \mathrm{H}_{2} \mathrm{O}$ was completely decomposed. However, alongside $\mathrm{CaF}_{2}$ and $\mathrm{CaCO}_{3}$, two diffraction peaks ( $d$-spacing: $0.762,0.385 \mathrm{~nm}$ ) - which did not correspond to any compound indexed in the PDF-4 database-were also noted (Figure 6). Calcium aluminates with unknown structures and compositions were probably formed during the leaching.

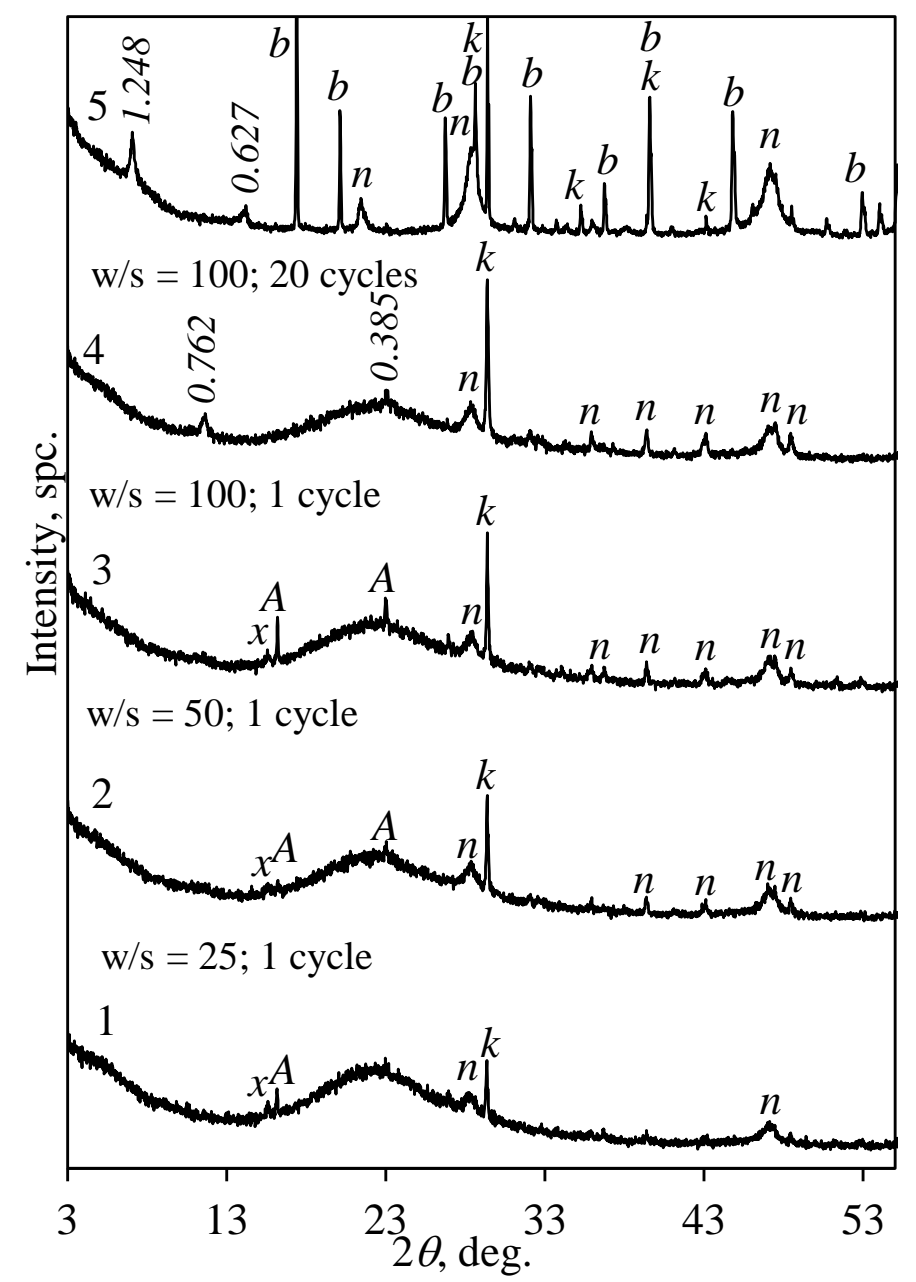

Figure 6. XRD patterns of the products obtained after the treatment of SGW with saturated $\mathrm{Ca}(\mathrm{OH})_{2}$ solution (curves 1-4) under dynamic conditions, and the precipitates formed in the liquid medium (curve 5). Indexes: $A-\mathrm{AlF}_{3} \cdot 3 \mathrm{H}_{2} \mathrm{O} ; n-\mathrm{CaF}_{2} ; x-\mathrm{AlF}_{1.5}(\mathrm{OH})_{1.5} \cdot 0.375 \mathrm{H}_{2} \mathrm{O} ; b-\mathrm{Ca}_{3} \mathrm{Al}_{2.85} \mathrm{O}_{2.55}(\mathrm{OH})_{9.45}$; $k-\mathrm{CaCO}_{3}$.

Regardless of the chosen treatment method (in cycles or not), fine solid particles were formed after the filtration in the liquid medium (Figure 7). For this reason, in order to induce the sedimentation and chemical reaction, the liquid medium was additionally maintained for $24 \mathrm{~h}$ under static conditions. Later on, the obtained precipitates were filtered and dried at $50 \pm 5{ }^{\circ} \mathrm{C}$ for $24 \mathrm{~h}$. The XRD analysis of the precipitates showed that, during the leaching experiments, $\mathrm{Ca}(\mathrm{OH})_{2}$ reacted with both fluoride and aluminum ions (formed by the decomposition of $\mathrm{AlF}_{3} \cdot 3 \mathrm{H}_{2} \mathrm{O}$ ) ions, which lead to the formation of $\mathrm{CaF}_{2}$ and katoite $\left(\mathrm{Ca}_{3} \mathrm{Al}_{2.85} \mathrm{O}_{2.55}(\mathrm{OH})_{9.45}, d\right.$-spacing: $\left.0.509,0.333,0.279 \mathrm{~nm}\right)$ in the products 
(Figure 6, curve 5). It is worth mentioning that $\mathrm{CaCO}_{3}$ and two diffraction maximums (d-spacing: 1.248, $0.627 \mathrm{~nm}$ ), which did not correspond to any compound indexed in the PDF-4 database, were observed in the XRD patterns of the obtained precipitates as well (Figure 6, curve 5). Based on the obtained results, it can be stated that the rate of $\mathrm{CaF}_{2}$ crystallization was great; therefore, this compound was detected in both the solid material and the precipitates. The obtained results were in good agreement with the literature data $[23,33,34]$.

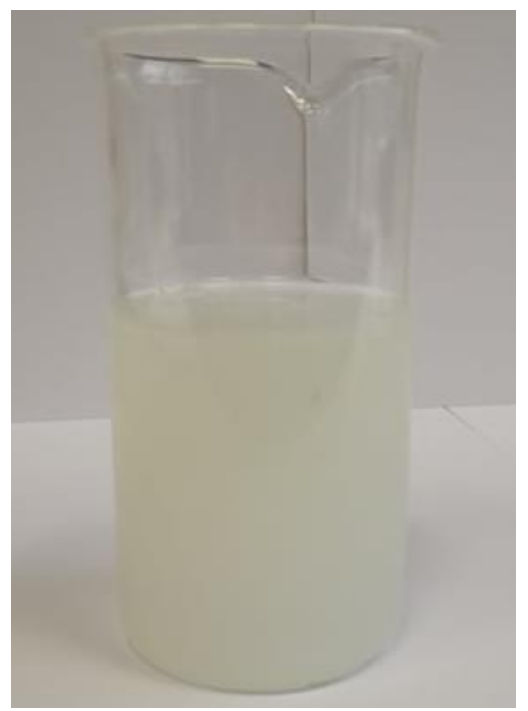

(a)

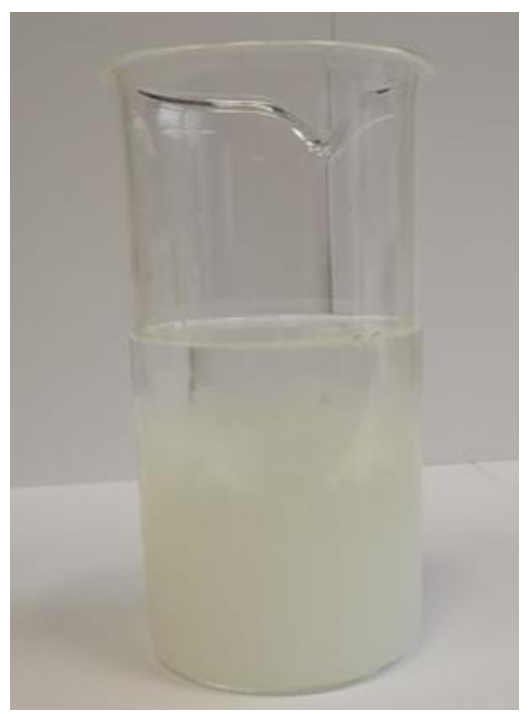

(b)

Figure 7. The optical images of the liquid medium obtained after the treatment of SGW with saturated $\mathrm{Ca}(\mathrm{OH})_{2}$ solution under dynamic conditions: (a) leaching by the use of continuous liquid medium flow $(\mathrm{w} / \mathrm{s}=100)$; (b) leaching in cycles $(\mathrm{w} / \mathrm{s}=100)$.

It was determined that, after the treatment of the SGW with the saturated $\mathrm{Ca}(\mathrm{OH})_{2}$ solution under dynamic conditions, the $\mathrm{pH}$ values of the liquid medium were greater than 8 , i.e., the liquid medium had alkaline properties (Table 3). Meanwhile, in a case of the samples with $\mathrm{Al}(\mathrm{OH})_{3}$, the $\mathrm{pH}$ of the liquid medium was acidic (Table 1). It was measured that the duration of the interaction (filtration) depends on the amount of water, and it increased from $55 \mathrm{~s}(\mathrm{w} / \mathrm{s}=25)$ to $283 \mathrm{~s}(\mathrm{w} / \mathrm{s}=100)$ (Table 3). The chemical analysis data of the treated SGW $(\mathrm{w} / \mathrm{s}=100)$ showed that the amount of $\mathrm{F}^{-}$ions released into the liquid medium was equal to $35.19 \%$ (Table 3 ). It is worth mentioning that the mentioned value was two times higher in comparison to the value obtained after the treatment of SGW without the additives (16.9\%) [19].

Table 3. The amount of $\mathrm{F}^{-}$ions and the $\mathrm{pH}$ values of the liquid medium in the SGW samples after the treatment with a saturated $\mathrm{Ca}(\mathrm{OH})_{2}$ solution under dynamic conditions.

\begin{tabular}{cccccc}
\hline $\begin{array}{c}\text { No. of } \\
\text { Cycles }\end{array}$ & $\begin{array}{c}\text { w/s } \\
\text { Ratio }\end{array}$ & $\begin{array}{c}\text { The Concentration of } \mathbf{F}^{-} \\
\text {Ions in the Sample, } \%\end{array}$ & $\begin{array}{c}\text { The Amount of } \\
\text { Released } \mathbf{F}^{-} \text {Ions, } \%\end{array}$ & $\begin{array}{c}\text { The pH Value of the } \\
\text { Liquid Medium }\end{array}$ & $\begin{array}{c}\text { The Duration of } \\
\text { Interaction, }\end{array}$ \\
\hline 25 & 1 & - & - & 8.61 & 55 \\
50 & 1 & - & - & 11.67 & 107 \\
100 & 1 & 6.50 & 35.19 & 12.03 & 283 \\
100 & 20 & 6.02 & 39.98 & - & - \\
\hline
\end{tabular}

It was determined that, after the treatment of the samples in cycles-already at the beginning of the process $(\mathrm{w} / \mathrm{s}=10)$ - the $\mathrm{pH}$ of the liquid medium was alkaline, i.e., $\mathrm{pH}>7$ (Figure 8, curve 2). Meanwhile, after 4 cycles $(\mathrm{w} / \mathrm{s}=20)$, the values of the $\mathrm{pH}$ of the liquid 
medium became equal to the ones of the initial solution, and the further increment in the $\mathrm{w} / \mathrm{s}$ ratio had no effect on the latter values. It was observed that, under these experimental conditions, the duration of the interaction (filtration) depended on the number of cycles, i.e., the duration increased with each cycle, and was more than five times longer at the end of the process (112 s) than at the beginning (21 s) (Figure 8, curve 1). Presumably, this was caused by the crystallization of $\mathrm{CaF}_{2}$ and/or $\mathrm{Ca}_{3} \mathrm{Al}_{2.85} \mathrm{O}_{2.55}(\mathrm{OH})_{9.45}$ in the filter pores. Although the duration of the interaction (filtration) was longer than it was in the samples with $\mathrm{Al}(\mathrm{OH})_{3}(40 \mathrm{~s})$, the amount of $\mathrm{F}^{-}$ions released into the liquid medium $(39.98 \%)$ during the treatment in cycles was $\sim 18 \%$ lower than the amount formed by the use of the $\mathrm{Al}(\mathrm{OH})_{3}$ additive (Tables 2 and 3). The greater amount of residual $\mathrm{F}^{-}$ions can be explained by the fact that $\mathrm{CaF}_{2}$ remains in the sample (Figure 6). The chemical analysis data of the liquid medium showed that all of the $\mathrm{F}^{-}$ions were combined to $\mathrm{CaF}_{2}$, because the mentioned ions' concentration did not exceed $0.001 \%$. Thus, the calcium ions influenced both the composition (mineral and chemical) and the properties of the silica gel waste and the liquid medium.

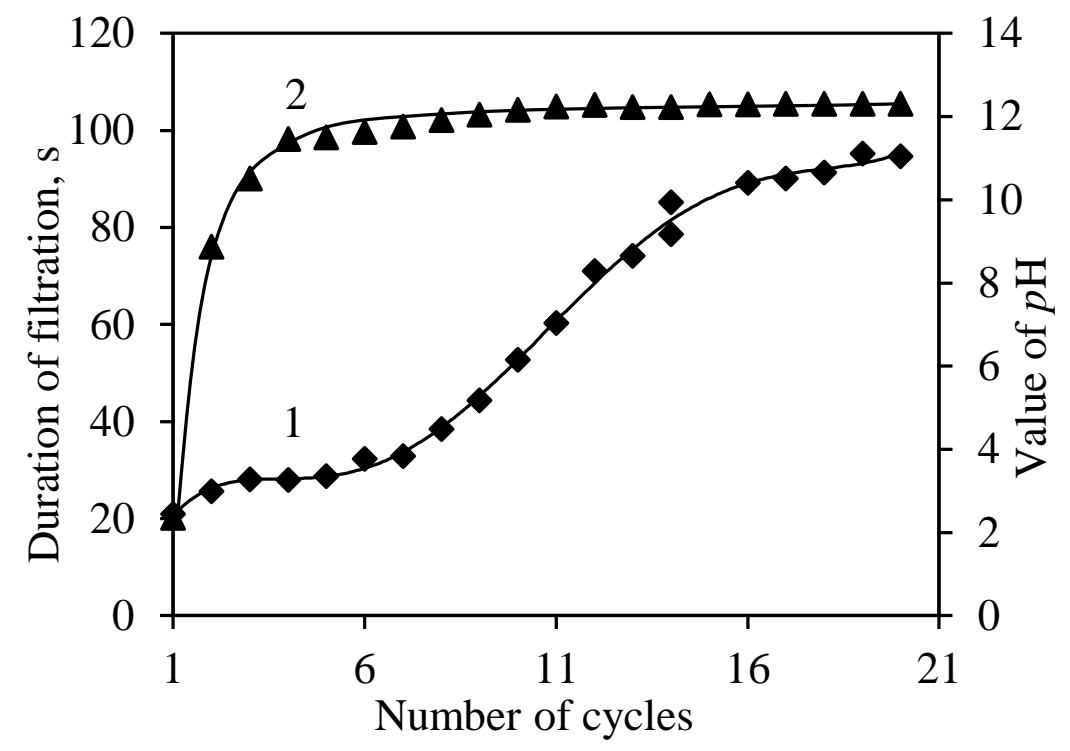

Figure 8. The change in the duration of the filtration (curve 1) and the $\mathrm{pH}$ values of the liquid medium (curve 2) during the treatment of the SGW with a saturated $\mathrm{Ca}(\mathrm{OH})_{2}$ solution in cycles.

As can be seen from the results obtained in parts 3.1 and 3.2, the hydroxide additives not only promote the release of fluorine ions into the liquid medium but also alter the mineral composition of the silica gel waste. Therefore, it was decided to treat the investigated samples with soluble alkaline solutions.

\subsection{The Effect of Alkaline Solutions on the Mobility of $F^{-}$Ions in Silica Gel Waste Samples}

In this part of work, the $\mathrm{NaOH}$ and $\mathrm{NH}_{4} \mathrm{OH}$ solutions were used for the leaching of the $\mathrm{F}^{-}$ions in the experiments. At the beginning, the treatment of the SGW with $0.01 \%$ and $0.05 \% \mathrm{NaOH}$ solutions under dynamic conditions was performed. It was determined that the $\mathrm{NaOH}$ solutions ( $\mathrm{w} / \mathrm{s}=20$ ) do not have a significant influence on the stability of $\mathrm{AlF}_{3} \cdot 3 \mathrm{H}_{2} \mathrm{O}$, because the intensities of the diffraction maximums typical to the latter only slightly decreased (Figure 9). Furthermore, low intensity diffraction peaks characteristic of $\mathrm{AlF}_{1.5}(\mathrm{OH})_{1.5} \cdot 0.375 \mathrm{H}_{2} \mathrm{O}$ were detected. 


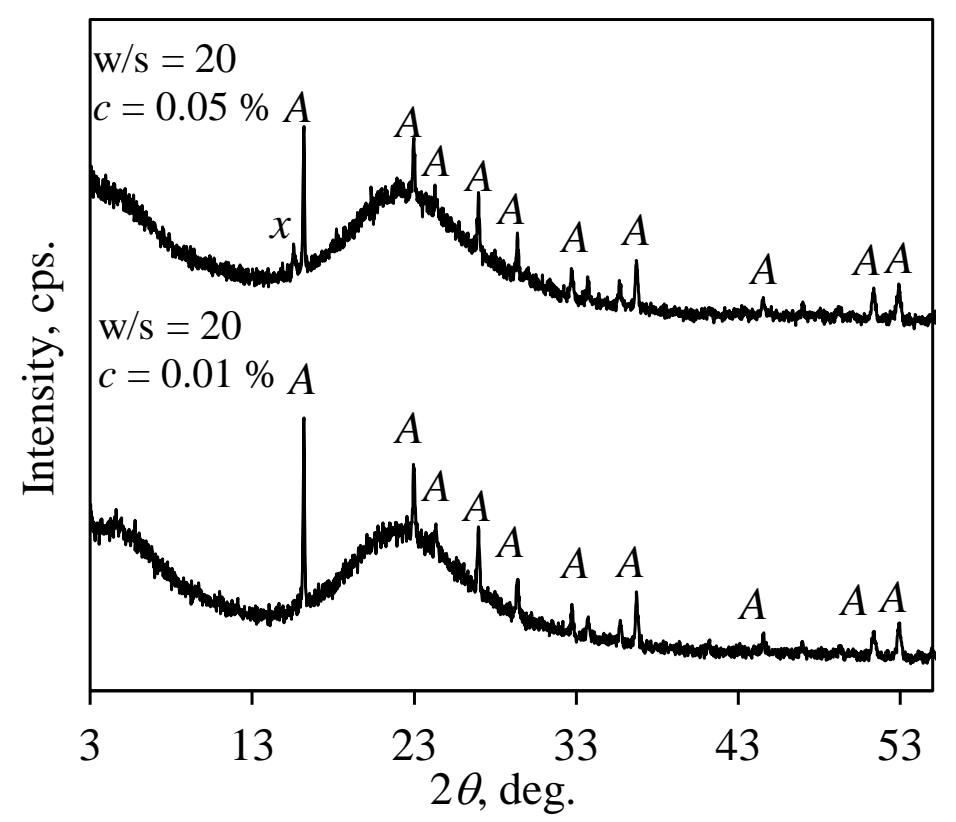

Figure 9. XRD patterns of the products obtained after the treatment of $\mathrm{SGW}$ with an $\mathrm{NaOH}$ solution in cycles. Indexes: $A-\mathrm{AlF}_{3} \cdot 3 \mathrm{H}_{2} \mathrm{O} ; x-\mathrm{AlF}_{1.5}(\mathrm{OH})_{1.5} \cdot 0.375 \mathrm{H}_{2} \mathrm{O}$.

Moreover, it was found that the duration of the interaction (Table 4) was very close to the one obtained by the treatment of the SGW sample with distillated water (20-30 s). Meanwhile, the $\mathrm{pH}$ value of the liquid medium had already reached more than 3 at the beginning of the process $(\mathrm{w} / \mathrm{s}=10)$. It should be indicated that the $\mathrm{pH}$ values of the initial $\mathrm{NaOH}$ solutions were equal to $11.17(0.01 \%)$ and $11.73(0.05 \%)$.

Table 4. The change in the $\mathrm{pH}$ values of the liquid medium and the duration of the interaction during the treatment with an $\mathrm{NaOH}$ solution in cycles.

\begin{tabular}{ccccc}
\hline & \multicolumn{4}{c}{ The Concentration of NaOH Solution, $\%$} \\
\cline { 2 - 5 } No. of Cycles & \multicolumn{2}{c}{$\mathbf{0 . 0 1}$} & \multicolumn{2}{c}{$\mathbf{0 . 0 5}$} \\
\cline { 2 - 5 } & $\begin{array}{c}\text { The pH Values of the } \\
\text { Liquid Medium }\end{array}$ & $\begin{array}{c}\text { The Duration of } \\
\text { Interaction, } \mathbf{s}\end{array}$ & $\begin{array}{c}\text { The pH Values of the } \\
\text { Liquid Medium }\end{array}$ & $\begin{array}{c}\text { The Duration of } \\
\text { Interaction, } \mathbf{s}\end{array}$ \\
\hline 1 & 2.08 & 29 & 2.13 & 24 \\
2 & 3.03 & 28 & 3.96 & 22 \\
3 & 4.15 & 27 & 6.92 & 34 \\
4 & 6.38 & 30 & 7.06 & 30 \\
\hline
\end{tabular}

The results of the chemical analysis showed that, after treatment with a $0.05 \% \mathrm{NaOH}$ solution $(\mathrm{w} / \mathrm{s}=20)$, the concentration of fluorine ions in the SGW sample decreased by $\sim 1.6$ times, i.e., to $6.23 \%$. Although the diffraction peaks characteristic of $\mathrm{AlF}_{3} \cdot 3 \mathrm{H}_{2} \mathrm{O}$ remained intensive, the intense release of fluorine ions into the liquid medium proceeded.

Due to the intense release of fluorine ions into the liquid medium, during the leaching experiments with the $\mathrm{NaOH}$ solution, it was decided to use $0.01 \%$ and $0.5 \%$ ammonia water solutions — which are currently applied in JSC 'Lifosa' — for further research.

The treatment of the SGW samples was performed in cycles when the maximum w/s ratio 20 was used (four cycles in total). It was determined that a slight decrease in the intensities of the diffraction peaks typical to $\mathrm{AlF}_{3} \cdot 3 \mathrm{H}_{2} \mathrm{O}$ was observed in the XRD patterns when the sample was treated with a $0.01 \%$ ammonia water solution $(\mathrm{w} / \mathrm{s}=20)$ (Figure 10). Meanwhile, after the treatment with a more highly-concentrated solution $(0.5 \%, \mathrm{w} / \mathrm{s}=10)$, it was noted that $\mathrm{AlF}_{3} \cdot 3 \mathrm{H}_{2} \mathrm{O}$ fully recrystallized to $\mathrm{Al}(\mathrm{OH}, \mathrm{F})_{3}(d$-spacing: $0.570,0.289,0.284$, $0.189 \mathrm{~nm}$ ). 


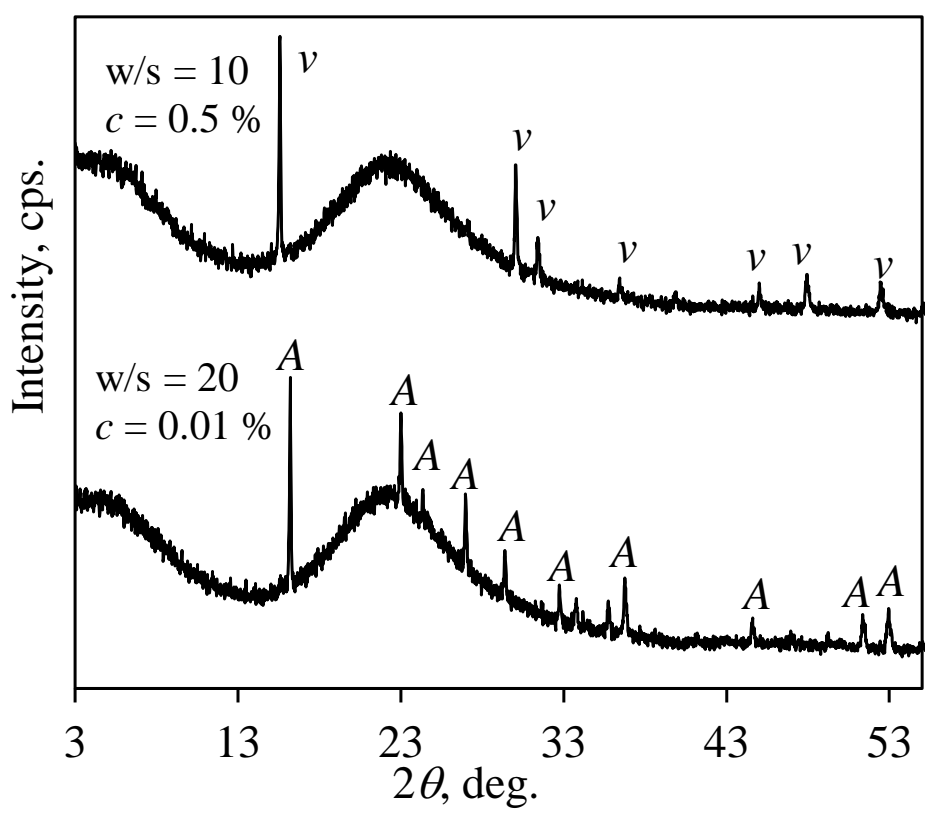

Figure 10. XRD patterns of products obtained after the treatment of $\mathrm{SGW}$ with $\mathrm{NH}_{4} \mathrm{OH}$ solution in cycles. Indexes: $A-\mathrm{AlF}_{3} \cdot 3 \mathrm{H}_{2} \mathrm{O} ; v-\mathrm{Al}(\mathrm{OH}, \mathrm{F})_{3}$.

It was measured that, when the silica gel waste was treated with $0.01 \%$ ammonia water, the filtration time and the $\mathrm{pH}$ values increased with the increasing $\mathrm{w} / \mathrm{s}$ ratio, and at the end of the experiment $(\mathrm{w} / \mathrm{s}=20)$ were equal to 55 and $6.54 \mathrm{~s}$, respectively (Table 5). Meanwhile, after the treatment with a higher concentration of the solution, the structure of the silica gel was destroyed, and fine particles clogged the pores of the filter, because even by applying vacuum $0.6-0.7$ bar, $900 \mathrm{~s}$ (cycle 1) and $6000 \mathrm{~s}$ (cycle 2) filtration durations were reached (Table 5). Thus, the $\mathrm{w} / \mathrm{s}$ ratio was not increased to 20 . It is worth noting that the $\mathrm{pH}$ values obtained in these conditions were $>8$.

Table 5. The change in the $\mathrm{pH}$ values of the liquid medium and the duration of the interaction during the treatment with $\mathrm{NH}_{4} \mathrm{OH}$ solution in cycles.

\begin{tabular}{|c|c|c|c|c|}
\hline \multirow{3}{*}{ No. of Cycles } & \multicolumn{4}{|c|}{ The Concentration of $\mathrm{NH}_{4} \mathrm{OH}$ Solution, \% } \\
\hline & \multicolumn{2}{|c|}{0.01} & \multicolumn{2}{|c|}{0.5} \\
\hline & $\begin{array}{l}\text { The pH Values of the } \\
\text { Liquid Medium }\end{array}$ & $\begin{array}{l}\text { The Duration of } \\
\text { Interaction, s }\end{array}$ & $\begin{array}{l}\text { The pH Values of the } \\
\text { Liquid Medium }\end{array}$ & $\begin{array}{l}\text { The Duration of } \\
\text { Interaction, s }\end{array}$ \\
\hline 1 & 2.02 & 26 & 8.51 & 900 \\
\hline 2 & 3.36 & 34 & 9.59 & 6000 \\
\hline 3 & 6.30 & 40 & - & - \\
\hline 4 & 6.54 & 55 & - & - \\
\hline
\end{tabular}

It was determined that the amount of $\mathrm{F}^{-}$ions released from the structure of the SGW sample into the liquid medium depends on the concentration of the $\mathrm{NH}_{4} \mathrm{OH}$ solution (Table 6). It was found that, after treatment with $0.01 \%$ ammonia water $(\mathrm{w} / \mathrm{s}=20)$, the amount of $\mathrm{F}^{-}$ions released was almost three times lower that than in the sample which was treated with $0.5 \%$ ammonia water $(\mathrm{w} / \mathrm{s}=10)(55.04 \%)$. It should be noted that a similar amount of fluorine ions were released into the liquid medium $(>50 \%)$ obtained by treating the SGW only with a high volume of water $(\mathrm{w} / \mathrm{s}=100)$ (Tables 1 and 2$)$. Thus, it can be stated that the structure of the SGW decomposes in $\mathrm{NH}_{4} \mathrm{OH}$ solution, and that the SGW lost its adsorption properties. 
Table 6. The amount of $\mathrm{F}^{-}$ions in contaminated silica gel samples after treatment with $\mathrm{NH}_{4} \mathrm{OH}$ solution under dynamic conditions.

\begin{tabular}{ccccc}
\hline No. of Cycles & w/s Ratio & $\begin{array}{c}\text { The Concentration of } \\
\mathbf{N H}_{\mathbf{4}} \text { OH Solution, \% }\end{array}$ & $\begin{array}{c}\text { The Concentration of } \mathbf{F}^{-} \\
\text {Ions in the Sample, \% }\end{array}$ & $\begin{array}{c}\text { The Amount of Released } \\
\mathbf{F}^{-}\end{array}$ \\
\hline 4 & 20 & 0.01 & 8.02 & 20.04 \\
2 & 10 & 0.5 & 4.51 & 55.04 \\
\hline
\end{tabular}

\subsection{The Effect of a Combined Treatment on the Mobility of $F^{-}$Ions in Silica Gel Waste Samples}

As can be seen from the results discussed above that the $\mathrm{pH}$ value of the liquid medium obtained after the treatment increases significantly with the addition of different hydroxide additives $\left(\mathrm{NH}_{4} \mathrm{OH}, \mathrm{Ca}(\mathrm{OH})_{2}, \mathrm{NaOH}\right)$ (Tables 3-6 and Figure 8). This is likely due to the peculiarities of the $\mathrm{AlF}_{3}$ production process; a significant amount of one of the starting materials, $\mathrm{H}_{2} \mathrm{SiF}_{6}$ acid, remained in the investigated sample, and it can theoretically be converted into soluble compounds only by the use of $\mathrm{KCl}$ and $\mathrm{NaOH}$ solutions:

$$
\begin{gathered}
2 \mathrm{KCl}+\mathrm{H}_{2} \mathrm{SiF}_{6} \rightarrow \mathrm{K}_{2} \mathrm{SiF}_{6}+2 \mathrm{HCl} \\
4 \mathrm{NaOH}+\mathrm{K}_{2} \mathrm{SiF}_{6} \rightarrow 2 \mathrm{KF}+4 \mathrm{NaF}+\mathrm{SiO}_{2}+2 \mathrm{H}_{2} \mathrm{O}
\end{gathered}
$$

Therefore, in the last stage of this research, the SGW was treated with $5 \% \mathrm{KCl}$ and $5 \% \mathrm{NaOH}$ solutions: the $\mathrm{KCl}$ solution $(\mathrm{w} / \mathrm{s}=0.5)$ was poured onto the sample, stirred vigorously for $5 \mathrm{~min}(60 \mathrm{rpm})$, and filtered off; later, the same procedure was repeated with an $\mathrm{NaOH}$ solution $(\mathrm{w} / \mathrm{s}=0.5)$, and, in the final step, the sample was treated with water $(\mathrm{w} / \mathrm{s}=0.5)$.

The results of the XRD analysis show that a slight decrease in the intensities of $\mathrm{AlF}_{3} \cdot 3 \mathrm{H}_{2} \mathrm{O}$ diffraction peaks was observed, when the SGW sample was treated with $\mathrm{KCl}$ solution (Figure 11). Meanwhile, $\mathrm{AlF}_{3} \cdot 3 \mathrm{H}_{2} \mathrm{O}$ recrystallized to a related compound, $\mathrm{Al}_{2}(\mathrm{OH})_{2.76} \mathrm{~F}_{3.24}\left(\mathrm{H}_{2} \mathrm{O}\right)$, after treatment with an $\mathrm{NaOH}$ solution (Figure 11). It was found that, due to the presence of $\mathrm{Al}^{3+}$ ions in the silica gel samples, the $\mathrm{F}^{-}$ions were bound to low solubility compounds- $\mathrm{K}_{2} \mathrm{NaAlF}_{6}$ (d-spacing: $0.287,0.234,0.203 \mathrm{~nm}$ ) and $\mathrm{Na}_{3} \mathrm{AlF}_{6}$ (d-spacing: $0.194,0.275,0.157 \mathrm{~nm}$ )—-therefore, they were identified even after the treatment with water (Figure 11).

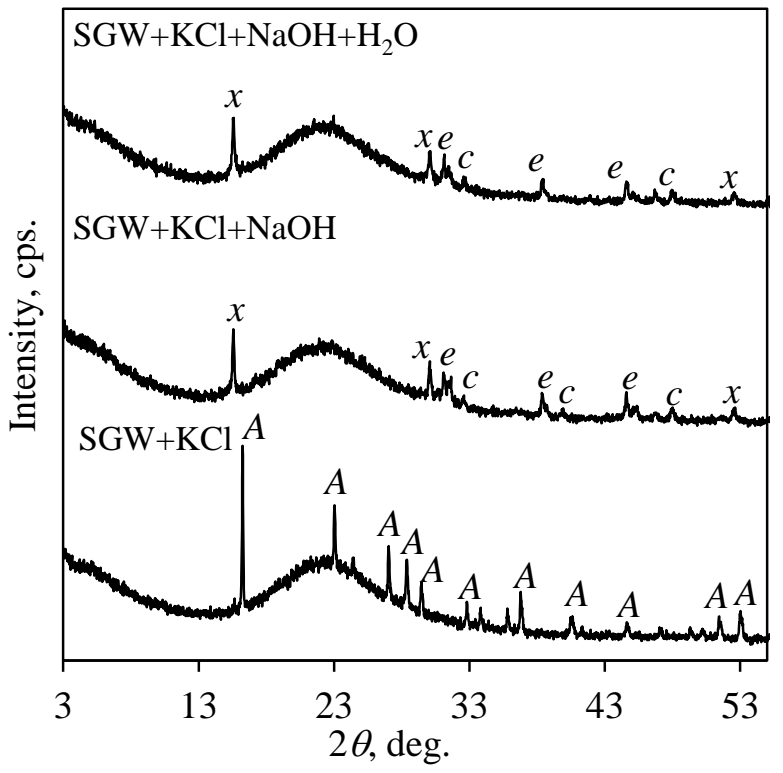

Figure 11. $\mathrm{XRD}$ patterns of the products obtained after the combined treatment of $\mathrm{SGW}$ with $\mathrm{KCl}$ and $\mathrm{NaOH}$. Indexes: $A-\mathrm{AlF}_{3} \cdot 3 \mathrm{H}_{2} \mathrm{O} ; x-\mathrm{Al}_{2}(\mathrm{OH})_{2.76} \mathrm{~F}_{3.24}\left(\mathrm{H}_{2} \mathrm{O}\right) ; e-\mathrm{K}_{2} \mathrm{NaAlF}_{6} ; c-\mathrm{Na}_{3} \mathrm{AlF}_{6}$. 
As JSC 'Lifosa' preferentially uses $\mathrm{NH}_{4} \mathrm{OH}$ in the production process, the $\mathrm{NaOH}$ solution was replaced with $5 \%$ ammonia water. It was found that the $\mathrm{AlF}_{3} \cdot 3 \mathrm{H}_{2} \mathrm{O}$ remained stable, as a slight decrease in the intensities of the diffraction peaks typical to the mentioned compound was observed in the $\mathrm{XRD}$ patterns (Figure 12). Besides this, $\mathrm{K}_{2} \mathrm{NaAlF}_{6}$ or $\mathrm{Na}_{3} \mathrm{AlF}_{6}$ did not form under these treatment conditions.

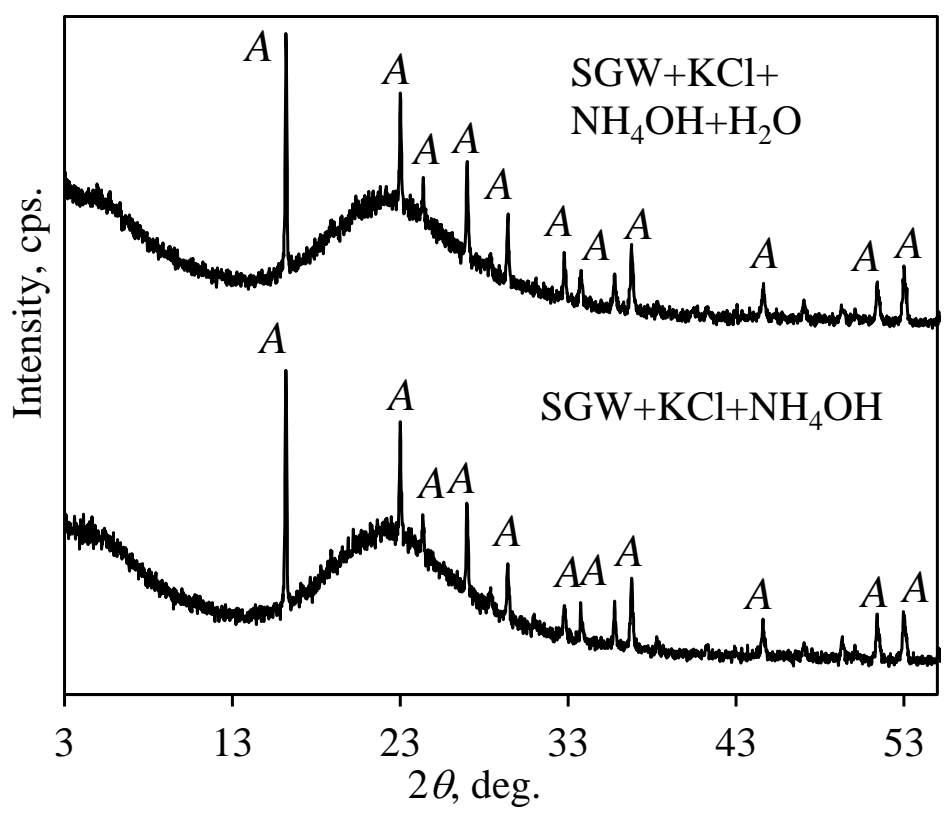

Figure 12. XRD patterns of the products obtained after the combined treatment of SGW with $\mathrm{KCl}$ and $\mathrm{NH}_{4} \mathrm{OH}$. Indexes: $A-\mathrm{AlF}_{3} \cdot 3 \mathrm{H}_{2} \mathrm{O}$.

It was also found that the SGW sample was neutralized when $\mathrm{KCl}$ and $\mathrm{NaOH}$ solutions were used together, as the $\mathrm{pH}$ value of the liquid medium was equal to 6.69 after the treatment with water (Table 7). Meanwhile, when the $\mathrm{NaOH}$ solution was replaced with $5 \%$ ammonia, the $\mathrm{pH}$ values were equal to 2.36 and 3.01. It should be noted that, after the leaching of the silica gel samples with ammonia water (without $\mathrm{KCl}$ ), the $\mathrm{pH}$ value of the liquid medium had already reached $>6$ at the beginning of the process (Table 5).

Table 7. The amount of $\mathrm{F}^{-}$ions and the $\mathrm{pH}$ values of the liquid medium in the SGW samples after the treatment with saturated $\mathrm{Ca}(\mathrm{OH})_{2}$ solution under dynamic conditions.

\begin{tabular}{cccc}
\hline $\begin{array}{c}\text { The Treatment } \\
\text { Conditions }\end{array}$ & $\begin{array}{c}\text { The Concentration of } \mathbf{F}^{-} \\
\text {Ions in the Sample, } \%\end{array}$ & $\begin{array}{c}\text { The Amount of Released } \mathbf{F}^{-} \\
\text {Ions, } \%\end{array}$ & $\begin{array}{c}\text { The pH Value of the Liquid } \\
\text { Medium }\end{array}$ \\
\hline $\mathrm{SGW}+\mathrm{KCl}$ & - & - & 1.96 \\
$\mathrm{SGW}+\mathrm{KCl}+\mathrm{NaOH}$ & - & - & 8.13 \\
$\mathrm{SGW}+\mathrm{KCl}+\mathrm{NaOH}+\mathrm{H}_{2} \mathrm{O}$ & 8.44 & 15.86 & 6.69 \\
$\mathrm{SGW}+\mathrm{KCl}+\mathrm{NH}_{4} \mathrm{OH}$ & - & - & 2.36 \\
$\mathrm{SGW}+\mathrm{KCl}+\mathrm{NH}_{4} \mathrm{OH}+\mathrm{H}_{2} \mathrm{O}$ & 8.73 & 12.97 & 3.01 \\
\hline
\end{tabular}

Thus, a combined treatment method was found to have no significant effect on the fluorine ion content in the investigated sample, as the concentration of these ions in the sample was reduced only by $13-16 \%$ (Table 7 ), which was four times lower than that in the sample which was treated with $\mathrm{NH}_{4} \mathrm{OH}$ (Table 6).

To summarise the results, it can be stated that, by the use of an $\mathrm{Al}(\mathrm{OH})_{3}$ additive, it is possible to reduce the concentration of $\mathrm{F}^{-}$ions in the sample from $10.0 \%$ to $\sim 4.5 \%$; however, a large amount of water is required for this process (w/s > 100) (Table 8). The amount of liquid medium required can be significantly reduced by the use of an $\mathrm{NH}_{4} \mathrm{OH}$ solution (Table 8). To our knowledge, the more successful results were obtained only by 
Krysztafkiewicz et al. [23]; the $\mathrm{F}^{-}$ions' concentration was reduced by eight times; however, the initial concentration of the mentioned ions was equal only to $1.6 \%$, and there is no data about the water-to-solid ratio.

Table 8. The treatment conditions under which the concentration of $\mathrm{F}^{-}$ions in the sample was reduced twice.

\begin{tabular}{cccccc}
\hline Additive & w/s Ratio & $\begin{array}{c}\text { Treatment } \\
\text { Conditions }\end{array}$ & $\begin{array}{c}\text { The Duration of } \\
\text { Interaction }\end{array}$ & $\begin{array}{c}\text { The pH Value of the } \\
\text { Liquid Medium }\end{array}$ & $\begin{array}{c}\text { The Concentration of } \mathbf{F}^{-} \\
\text {Ions in the Sample, } \%\end{array}$ \\
\hline- & - & - & - & - & 10.0 \\
$\mathrm{Al}(\mathrm{OH})_{3}$ & 100 & Static & $24 \mathrm{~h}$ & 3.06 & 4.47 \\
$\mathrm{Al}(\mathrm{OH})_{3}$ & 100 & Dynamic & 13 min & 4.2 & 4.22 \\
$\mathrm{NH}_{4} \mathrm{OH}$ solution & 10 & Dynamic & $2 \mathrm{~h}$ & $>7$ & 4.51 \\
\hline
\end{tabular}

In the future research, the treated silica gel waste will be used as an $\mathrm{SiO}_{2}$ source for the production of environmentally-friendly cementitious materials.

\section{Conclusions}

(1) The treatment method and additives were found to have a significant effect on the mineralogical composition of the silica gel waste samples. It was determined that the amount of the $\mathrm{Al}(\mathrm{OH})_{3}$ additive did not affect the stability of the $\mathrm{AlF}_{3} \cdot 3 \mathrm{H}_{2} \mathrm{O}$; however, by increasing w/s ratio from 20 to 100 , only a small amount of $\mathrm{AlF}_{3} \cdot 3 \mathrm{H}_{2} \mathrm{O}$ was present in the sample. Meanwhile, when a $\mathrm{Ca}(\mathrm{OH})_{2}$ additive or a saturated $\mathrm{Ca}(\mathrm{OH})_{2}$ solution were used, the formation of $\mathrm{CaF}_{2}$ in the silica gel waste was observed.

(2) It was found that, in the case of $\mathrm{Al}(\mathrm{OH})_{3}$ or $\mathrm{Ca}(\mathrm{OH})_{2}$ additives, a significant reduction ( $\sim 2$ times) of the fluorine ions in the silica gel waste can be achieved only by applying the treatment with a high quantity of liquid medium $(\mathrm{w} / \mathrm{s}=100)$. Meanwhile, by the use of $\mathrm{NaOH}$ or $\mathrm{NH}_{4} \mathrm{OH}$ solutions $(\mathrm{w} / \mathrm{s}=20)$, the concentration of fluorine ions in the silica gel waste can be reduced by 1.6 and 2.2 times, respectively.

(3) It was determined that the compounds containing aluminum and fluorine ionssuch as $\mathrm{AlF}_{3}, \mathrm{CaF}_{2}$ and $/$ or $\mathrm{Ca}_{3} \mathrm{Al}_{2.85} \mathrm{O}_{2.55}(\mathrm{OH})_{9.45}$ - were crystallized in the liquid medium, which was separated from the silica gel by the application of leaching with alkaline solutions.

(4) The fluoride ions were found to be most efficiently removed from the silica gel waste when treatment with an $\mathrm{NH}_{4} \mathrm{OH}$ solution under dynamic conditions $(\mathrm{w} / \mathrm{s}=10)$ was applied, as the amount of fluorine ions released into the liquid medium was $>50 \%$. The resulting reaction medium, after the precipitation of aluminum fluoride trihydrate, can be reused for the treatment of contaminated silica gel samples.

Author Contributions: This paper was written using contributions from all of the authors. Conceptualization, T.D. and K.B.; methodology, T.D.; formal analysis, V.R., A.G. and T.D.; investigation, V.R.; data curation, K.B.; writing — original draft preparation, V.R. and T.D.; writing—review and editing, T.D. and A.G.; visualization, A.G. and V.R.; supervision, K.B.; funding acquisition, T.D. All authors have read and agreed to the published version of the manuscript.

Funding: This research was supported by the Research and Innovation Fund of Kaunas University of Technology (No. PP59/2002) and by JSC 'Lifosa'. The APC was funded by Faculty of chemical technology, Kaunas university of technology.

Institutional Review Board Statement: Not applicable.

Informed Consent Statement: Not applicable.

Data Availability Statement: The data that support the findings of this study are available from the corresponding author, T.D., upon reasonable request.

Conflicts of Interest: The authors declare no conflict of interest. 


\section{References}

1. Pesqueira, F.J.R.; Fernando, M.; Pereira, R.; Silva, A.M.T. Environmental impact assessment of advanced urban wastewater treatment technologies for the removal of priority substances and contaminants of emerging concern: A review. J. Clean. Prod. 2020, 261, 121078. [CrossRef]

2. Moh, Y.C.; Abd Manaf, L. Solid waste management transformation and future challenges of source separation and recycling practice in Malaysia. Resour. Conserv. Recycl. 2017, 116, 1-14. [CrossRef]

3. Sadhukhan, J.; Dugmore, T.I.J.; Matharu, A.; Martinez-Hernandez, E.; Aburto, J.; Rahman, P.K.S.M.; Lynch, J. Perspectives on "Game Changer" Global Challenges for Sustainable 21st Century: Plant-Based Diet, Unavoidable Food Waste Biorefining, and Circular Economy. Sustainability 2020, 12, 1976. [CrossRef]

4. Soliman, N.K.; Moustafa, A.F. Industrial solid waste for heavy metals adsorption features and challenges; a review. J. Mater. Res. Technol. 2020, 9, 10235-10253. [CrossRef]

5. Eurostat. Waste Statistics. Available online: https://ec.europa.eu/eurostat/statistics-explained/index.php/Waste_statistics (accessed on 14 January 2021).

6. Sohoo, I.; Ritzkowski, M.; Kuchta, K.; Cinar, S.Ö. Environmental Sustainability Enhancement of Waste Disposal Sites in Developing Countries through Controlling Greenhouse Gas Emissions. Sustainability 2021, 13, 151. [CrossRef]

7. Khanyile, A.; Caws, G.C.; Nkomo, S.L.; Mkhize, N.M. Characterisation Study of Various Disposable Diaper Brands. Sustainability 2020, 12, 10437. [CrossRef]

8. Golwala, H.; Zhang, X.; Iskander, S.M.; Smith, L.M. Solid Waste: An Overlooked Source of Microplastics to the Environment. Sci. Total Environ. 2021, 769, 144581.

9. Torretta, V.; Ferronato, N.; Katsoyiannis, I.A.; Tolkou, A.K.; Airoldi, M. Novel and Conventional Technologies for Landfill Leachates Treatment: A Review. Sustainability 2017, 9, 9. [CrossRef]

10. Woźniak, J.; Pactwa, K. Overview of polish mining wastes with circular economy model and its comparison with other wastes. Sustainability 2018, 10, 3994. [CrossRef]

11. Dreveton, A. Manufacture of Aluminium Fluoride of High Density and Anhydrous Hydrofluoric Acid from Fluosilicic Acid. Procedia Eng. 2012, 46, 255-265. [CrossRef]

12. O'Driscoll, M. China Supply Shortages Hit Consumers as New Sources Emerge. 2017. Available online: http://imformed.com/ wp-content/uploads/2017/09/AIT-Fluorspar-for-AlF3.pdf (accessed on 14 January 2021).

13. Dreveton, A. Overview of the Fluorochemicals Industrial Sectors. Procedia Eng. 2016, 138, 240-247. [CrossRef]

14. EUROPEAN COMMISSION. Selected Illustrative LVIC-S Industry Products. Integrated Pollution Prevention and Control Reference Document on Best Available Techniques for the Manufacture of Large Volume Inorganic Chemicals—Solids and Other Industry. 2007. Available online: https:/ / eippcb.jrc.ec.europa.eu/sites/default/files/2019-11/lvic-s_bref_0907.pdf (accessed on 14 January 2021).

15. Coggins, A. Aluminium Fluoride and Aluminium: 2019 Trends and Outlook to 2029. Fluorine Forum 2019. 2019. Available online: http:/ /imformed.com/wp-content/uploads/2019/10/COGGINS-Fluorine-Forum-2019-IMFORMED.pdf (accessed on 14 January 2021).

16. Krysztafkiewicz, A.; Rager, B.; Maik, M. Silica recovery from waste obtained in hydrofluoric acid and aluminum fluoride production from fluosilicic acid. J. Hazard. Mater. 1996, 48, 31-49. [CrossRef]

17. Vaičiukynienè, D.; Vaitkevičius, V.; Kantautas, A.; Sasnauskas, V. Utilization of by-product waste silica in concrete-based materials. Mat. Res. 2012, 15, 561-567. [CrossRef]

18. Dreveton, A. Economic Aspects of Utilizing Fluosilicic Acid as Raw Material for the Manufacture of Hydrofluoric Acid and Aluminium Fluoride. Procedia Eng. 2014, 83, 279-285. [CrossRef]

19. Rudelis, V.; Dambrauskas, T.; Grineviciene, A.; Baltakys, K. The Prospective Approach for the Reduction of Fluoride Ions Mobility in Industrial Waste by Creating Products of Commercial Value. Sustainability 2019, 11, 634. [CrossRef]

20. Vaičiukynienè, D.; Kantautas, A.; Vaitkevičius, V.; Jakevičius, L.; Rudžionis, Ž.; Paškevičius, M. Effects of ultrasonic treatment on zeolite NaA synthesized from by-product silica Ultrason. Sonochemistry 2015, 27, 515-521. [CrossRef]

21. Baltakys, K.; Iljina, A.; Bankauskaite, A. Thermal properties and application of silica gel waste contaminated with F-ions for C-S-H synthesis. J. Therm. Anal. Calorim. 2015, 121, 145-154. [CrossRef]

22. Iljina, A.; Baltakys, K.; Baltakys, M.; Siauciunas, R. Neutralization and removal of compounds containing fluoride ions from waste silica gel. Rev. Rom. Mater. 2014, 44, 265-271.

23. Krysztafkiewicz, A.; Jesionowski, T.; Świt, Z. Evaluation of waste silica precipitated in the process of hydrofluoric acid production from fluosilicic acid. Physicochem. Probl. Miner. Process. 2005, 39, 165-176.

24. Kaminskas, R.; Kubiliute, R. Artificial pozzolana from silica gel waste-clay-limestone composite. Adv. Cem. Res. 2014, 26, 155-168. [CrossRef]

25. Vaičiukynienè, D.; Jakevičius, L.; Kantautas, A.; Vaitkevičius, V.; Vaičiukynas, V.; Dvořák, K. Conversion of silica by-product into zeolites by thermo-sonochemical treatment. Ultrason. Sonochem. 2021, 72, 105426. [CrossRef]

26. Vaičiukynienė, D.; Kantautas, A.; Vaitkevičius, V.; Sasnauskas, V. Using of Modified $\mathrm{AlF}_{3}$ Production Waste in Cement-Based. Mater. Sci. 2009, 15, 255-261.

27. Vaičiukynienè, D.; Borg, R.P.; Kielè, A.; Kantautas, A. Alkali-activated blends of calcined $\mathrm{AlF}_{3}$ production waste and clay. Ceram. Int. 2008, 44, 12573-12579. [CrossRef] 
28. Krivenko, P.; Vaičiukynienè, D.; Kantautas, A.; Vaitkevičius, V.; Šerelis, E. Effect of $\mathrm{AlF}_{3}$ production waste on the processes of hydration and hardening of the alkali-activated Portland cement with sodium silicate hydrate. J. Therm. Anal. Calorim. 2019, 138, 879-887. [CrossRef]

29. Kaminskas, R.; Cesnauskas, V.; Kubiliute, R. Influence of different artificial additives on Portland cement hydration and hardening. Constr. Build. Mater. 2015, 95, 537-544. [CrossRef]

30. Kaminskas, R.; Kubiliute, R. The Pozzolanic activity of calcined clay-Silica gel composites. Mater. Sci. 2013, 19, 453-460.

31. Iljina, A.; Baltakys, K.; Bankauskaite, A.; Eisinas, A.; Kitrys, $\mathrm{S}$. The stability of formed $\mathrm{CaF}_{2}$ and its influence on the thermal behavior of C-S-H in CaO-silica gel waste- $\mathrm{H}_{2} \mathrm{O}$ system. J. Therm. Anal. Calorim. 2017, 127, 221-228. [CrossRef]

32. Sarkar, R.; Ghosh, S.; Das, S.K. Waste Silica from aluminum fluoride industries used for ceramic whitewares. Am. Ceram. Soc. Bull. 2007, 86, 9201-9205.

33. Aldaco, R.; Garea, A.; Irabien, A. Calcium fluoride recovery from fluoride wastewater in a fluidized bed reactor. Water Res. 2007, 41, 810-818. [CrossRef]

34. Gogoi, S.; Nath, S.K.; Bordoloi, S.; Dutta, R.K. Fluoride removal from groundwater by limestone treatment in presence of phosphoric acid. J. Environ. Manag. 2015, 152, 132-139. [CrossRef] 